\title{
A 40-year High Arctic climatological dataset of the Polish Polar Station Hornsund (SW Spitsbergen, Svalbard)
}

\author{
Tomasz Wawrzyniak and Marzena Osuch \\ Institute of Geophysics, Polish Academy of Sciences, Warsaw, Poland \\ Correspondence: Tomasz Wawrzyniak (tomasz@igf.edu.pl)
}

Received: 8 November 2019 - Discussion started: 20 December 2019

Revised: 28 February 2020 - Accepted: 5 March 2020 - Published: 3 April 2020

\begin{abstract}
The article presents the climatological dataset from the Polish Polar Station Hornsund located in the southwest part of Spitsbergen - the biggest island of the Svalbard archipelago. Due to a general lack of long-term in situ measurements and observations, the High Arctic remains one of the largest climate-data-deficient regions on the Earth. Therefore, the described time series of observations in this paper are of unique value. To draw conclusions on the climatic changes in the Arctic, it is necessary to analyse and compare the long-term series of continuous, in situ observations from different locations, rather than relying on the climatic simulations only. In recent decades, rapid environmental changes occurring in the Atlantic sector of the Arctic are reflected in the data series collected by the operational monitoring conducted at the Hornsund station. We demonstrate the results of the 40-year-long series of observations. Climatological mean values or totals are given, and we also examined the variability of meteorological variables at monthly and annual scale using the modified Mann-Kendall test for trend and Sen's method. The relevant daily, monthly, and annual data are provided on the PANGAEA repository (https://doi.org/10.1594/PANGAEA.909042, Wawrzyniak and Osuch, 2019).
\end{abstract}

\section{Introduction}

For the analysis of the Arctic climate change, the long-term operational monitoring of meteorological variables including reliable observations and measurements is obligatory. Weather conditions are crucial drivers that have feedback on many environmental components, and it is important to have a relevant dataset of atmospheric observation data when analysing the variability and fluctuations of climate at any given location. Climate change in the Arctic reflects a global warming trend, but the warming here is much faster than in lower latitudes (IPCC, 2019). The characteristics of Earth's climate zones are primarily determined by astronomical factors, but there are differences in the mechanisms that cause a regional warming trend and determine their magnitude. The presence of solar radiation, modified by the degree of cloudiness and type of clouds, is the main factor influencing the transfer of energy. In polar regions during the polar night, the sole source of energy is the dynamic advec- tion of heat from the oceanic and atmospheric circulations with regional differences throughout the area. Mechanisms of Arctic amplification are still not fully understood but include feedback of reduced summer albedo due to reduction of sea ice extent and snow cover loss, higher sea surface temperatures, an increase of atmospheric water vapour content, cloud conditions, and changes in atmospheric circulation (IPCC, 2019). The growing number of positive annual air temperature anomalies in the Arctic varies substantially within the region, with the strongest changes observed in the Atlantic sector (Przybylak, 2016). Here, the Greenland Sea to the west of Svalbard is dominated by the West Spitsbergen Current, carrying warm $\left(3-6^{\circ} \mathrm{C}\right)$ and salty $(>35 \%$ ) Atlantic waters towards the Fram Strait. In this region, this flow is over $200 \mathrm{~km}$ wide and strongly influences the air temperature in the SW Spitsbergen area, especially during the winter (Walczowski et al., 2017). The specific maritime and mild climatic conditions are also influenced by local and regional factors such as sea ice cover and its distribution (Dahlke et 
al., 2020), the presence of glaciers, orography of the terrain, and location near the seashore. The climatic variables such as air temperature, humidity, and precipitation vary significantly across the archipelago (Nordli et al., 2014; Osuch and Wawrzyniak, 2017a) as well as around the Hornsund fjord (Araźny et al., 2018). Long-term, high-quality, in situ consistent meteorological observations have been collected at the Hornsund station located at the northern shore of this fjord. Relative to the other parts of the Arctic, air temperatures in Svalbard are the highest at this latitude and their observed changes are one of the largest on Earth (IPCC, 2019). There is evidence for anomalies and changes in recent years in Atlantic sector of the Arctic, along western Spitsbergen, including higher air temperature (Gjelten et al., 2016) and higher liquid precipitation (Osuch and Wawrzyniak, 2017a). These changes have many environmental implications, leading to prolongation of the ablation season (Osuch and Wawrzyniak, $2017 \mathrm{~b}$ ), the negative mass balance of glaciers (van Pelt et al., 2019), and permafrost degradation (Wawrzyniak et al., 2016).

\section{Study area}

The Stanisław Siedlecki Polish Polar Station in Hornsund $\left(77^{\circ} 00^{\prime} \mathrm{N} 15^{\circ} 33^{\prime} \mathrm{E}\right)$, located $300 \mathrm{~m}$ from the shore of the Isbjørnhamna Bay of the Hornsund fjord in SW Spitsbergen (Fig. 1), was established during the International Geophysical Year in 1957. Since 1978 it has conducted year-round scientific research, and it is the northernmost permanent Polish scientific site, which throughout the years has become a modern interdisciplinary scientific platform that carries out research projects aimed at a better understanding of the functioning of the arctic nature and the changes it undergoes. The Hornsund fjord is approximately $35 \mathrm{~km}$ long and approximately $14.5 \mathrm{~km}$ wide at its mouth to the Greenland Sea. The coastline of Hornsund is diversified, with multiple bays and glaciated valleys. A recent expansion of the ice-free areas is observed in Svalbard, with the most significant retreats of the tidewater glaciers (Błaszczyk et al., 2013), so the recognition of the changes in the functioning of the environmental system becomes more and more essential. The station is set on a marine terrace at $10 \mathrm{~m}$ a.s.l. This terrace, raised during Holocene (Lindner et al., 1991), consists of sea gravel and is covered by a diversity of tundra vegetation types. The slopes of the nearest mountain ranges Fugleberget $(569 \mathrm{~m})$ and Ariekammen $(517 \mathrm{~m})$ are located $1 \mathrm{~km}$ north from the station. Around $800 \mathrm{~m}$ NE from the station lies the lateral moraine of Hansbreen glacier. Currently, the distance from the station to the front of Hansbreen is around $2.5 \mathrm{~km}$. The ground here has a continuous permafrost layer down to more than $100 \mathrm{~m}$ deep (Wawrzyniak et al., 2016).

At Hornsund meteorological site (indexed by international numbering system 01003 (https://oscar.wmo.int/surface/, last access: 1 April 2020), managed by the Institute of Geo- physics Polish Academy of Sciences), year-round, systematic, continuous measurements and observations at WMO standards have been conducted since July 1978. The results of automatic measurements and visual observations are sent as the SYNOP code to WMO database every $60 \mathrm{~min}$ and $3 \mathrm{~h}$, respectively. Since January 2001 most of the traditional instruments had been replaced by an automatic weather station with Vaisala QLC-50 logger. The sensors of the new system have been installed on meteorological mast, situated $160 \mathrm{~m}$ SW of the main station building. To replace Vaisala QLC50, in September 2016 a new system called Vaisala MAWS 301 was set on the same meteorological mast. To determine the degree of compatibility and homogeneity of the measurements, the old and new sensors were operating simultaneously for more than 1 year. The results of the analysis allowed us to combine time series; since January 2018 the data have come from Vaisala MAWS 301. A comprehensive description of measurements and instruments can be found in a collective work edited by Marsz and Styszyńska (2013) and in Table 1. Although the time series of the data stretches up to July 1978, here we analyse the variability of climatic conditions over the period 1979-2018 and in some cases 19832018 , based on the availability of observations without gaps. The daily, monthly, and annual averages or sums, and the extreme range (min and max) computed from observations are provided in the scientific digital data repository PANGAEA (Wawrzyniak and Osuch, 2019).

\section{Meteorological variables}

Interseasonal weather fluctuations are determined by the changing Arctic climate system and atmospheric circulation. The changing global climate also modifies regional conditions. Weather conditions are crucial factors that have local feedback on many environmental components. Meteorological variables collected at the Hornsund station help to characterise the climate variability in this part of the Arctic and for a long time have been the background for multiple studies conducted in the SW Spitsbergen (Osuch and Wawrzyniak, 2017b; Wawrzyniak et al., 2017). Due to the diurnal variability of all meteorological variables, in this study, we use descriptive statistic methods to present the course and variation of multiple parameters. For most meteorological parameters, monthly mean values are calculated from daily mean values which are retrieved using the 3-hourly values (eight values a day, between 00:00 and 21:00 UTC), in the case of precipitation 6-hourly values (12:00, 18:00, and 00:00, 06:00 UTC of the following day), and daily sum of total solar radiation from Campbell-Stokes recorder obtained at the midnight.

\subsection{Air temperature}

Air temperature (TA) can be presumed to be one of the most sensitive indicators of climatic changes. The time series of daily TA from the Hornsund station covers the period 1979 


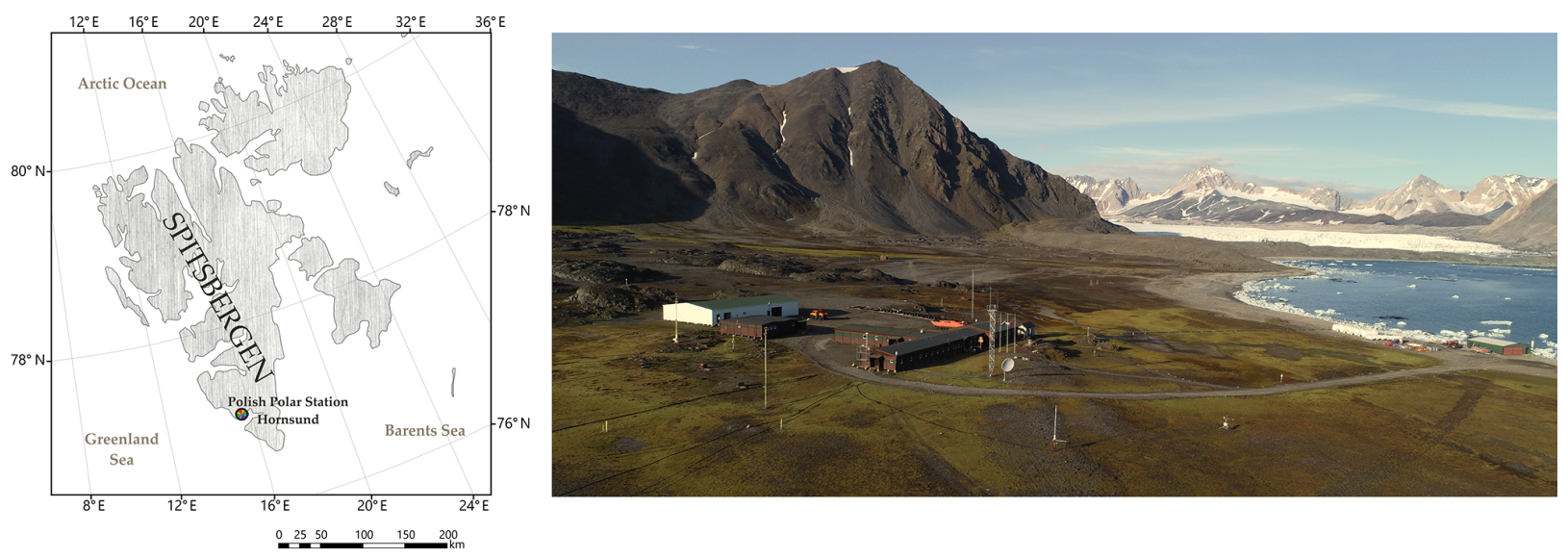

Figure 1. Polish Polar Station Hornsund on Spitsbergen in the Svalbard archipelago.

Table 1. Meteorological data measured at Hornsund including variables, current sensors, the period of operation, height, units, and their annual averages or sums.

\begin{tabular}{|c|c|c|c|c|c|c|}
\hline Variable & Location & Sensor & Period of operation & Height & Unit & Mean/sum \\
\hline $\begin{array}{l}\text { Air temperature } \\
\text { (TA) }\end{array}$ & $\begin{array}{l}77^{\circ} 00^{\prime} 1.261^{\prime \prime} \mathrm{N} \\
15^{\circ} 32^{\prime} 12.267^{\prime \prime} \mathrm{E}\end{array}$ & $\begin{array}{l}\text { Traditional thermometer in a Stevenson } \\
\text { screen, } \\
\text { Vaisala HMP 45D (since January } \\
\text { 2001), } \\
\text { HMP155 (since January 2018) }\end{array}$ & 1979-2018 & $2 \mathrm{~m}$ a.g.l. & ${ }^{\circ} \mathrm{C}$ & $\begin{array}{l}\mathrm{TA}_{\max }=-1.3 \\
\mathrm{TA}_{\text {mean }}=-3.7 \\
\mathrm{TA}_{\text {min }}=-6.0\end{array}$ \\
\hline $\begin{array}{l}\text { Relative } \\
\text { humidity (RH) }\end{array}$ & $\begin{array}{l}77^{\circ} 00^{\prime} 1.261^{\prime \prime} \mathrm{N} \\
15^{\circ} 32^{\prime} 12.267^{\prime \prime} \mathrm{E}\end{array}$ & $\begin{array}{l}\text { Hygrometer, HMP45D (since January } \\
\text { 2001), HMP155 (since January 2018) }\end{array}$ & $\begin{array}{l}\text { 1979-2018 with } \\
\text { gap } 1 \text { July-16 Au- } \\
\text { gust } 1982\end{array}$ & $2 \mathrm{~m}$ a.g.l. & $\%$ & 79.7 \\
\hline Precipitation & $\begin{array}{l}77^{\circ} 00^{\prime} 5.734^{\prime \prime} \mathrm{N} \\
15^{\circ} 32^{\prime} 17.077^{\prime \prime} \mathrm{E}\end{array}$ & Hellmann rain gauge D-200 & 1979-2018 & $1 \mathrm{~m}$ a.g.l. & $\mathrm{mm}$ & 478 \\
\hline $\begin{array}{l}\text { Atmospheric } \\
\text { pressure (PA) }\end{array}$ & $\begin{array}{l}77^{\circ} 00^{\prime} 1.261^{\prime \prime} \mathrm{N} \\
15^{\circ} 32^{\prime} 12.267^{\prime \prime} \mathrm{E}\end{array}$ & $\begin{array}{l}\text { Mercury barometer, PTB200A (since } \\
\text { January 2001), } \\
\text { Baro-1QML-AV (since January 2018) }\end{array}$ & $1983-2018$ & $\begin{array}{l}\text { Reduced to the } \\
\text { sea level }\end{array}$ & $\mathrm{hPa}$ & 1008.7 \\
\hline $\begin{array}{l}\text { Wind speed } \\
\text { (WS) and } \\
\text { direction (WD) }\end{array}$ & $\begin{array}{l}77^{\circ} 00^{\prime} 1.261^{\prime \prime} \mathrm{N} \\
15^{\circ} 32^{\prime} 12.267^{\prime \prime} \mathrm{E}\end{array}$ & $\begin{array}{l}\text { Fuess 90z wind meter, } \\
\text { Vaisala WAA151 (since January 2001), } \\
\text { Vaisala WMT702 (since January 2018) }\end{array}$ & $\begin{array}{l}1983-2000 \\
2001-2016 \\
2017-2018\end{array}$ & $10 \mathrm{~m}$ a.g.l. & $\mathrm{ms}^{-1}$ & 5.5 \\
\hline $\begin{array}{l}\text { Sunshine } \\
\text { duration (SD) }\end{array}$ & $\begin{array}{l}77^{\circ} 00^{\prime} 5.935^{\prime \prime} \mathrm{N} \\
15^{\circ} 32^{\prime} 14.3^{\prime \prime} \mathrm{E}\end{array}$ & Campbell-Stokes heliograph & $1979-2018$ & 2 m a.g.l. & $\mathrm{h}$ & 1030.8 \\
\hline Cloudiness & On location & Visual observations & 1983-2018 & & octas & 5.85 \\
\hline Visibility & On location & Visual observations & $1983-2018$ & & marine scale & 7.40 \\
\hline
\end{tabular}

to 2018. In the case of daily mean TA, there are no gaps in data, while for maximum and minimum, daily TA data for 1 September 1979, 29 February 1980, 15 June 2012, and 19 June 2017 are missing. Figure 2a presents the variability of the annual mean of minimum, mean, and maximum TA in 1979-2018 at the Hornsund station. An upward trend is clearly visible for the three analysed variables. The significance of the trend was estimated by the modified MannKendall test (Mann, 1945; Kendall, 1975; Hamed and Rao, 1998) taking into account autocorrelation of time series. The slope of the trend was estimated using Sen's method (Sen, 1968), where the slope is calculated as a median of the slopes of all pairs of points. The outcomes of the modified Mann-
Kendall indicated that the trends are statistically significant; the estimated $p$ value is very small (less than $1 \times 10^{-7}$ ) for three presented variables.

The estimated slope of trend equal to $1.34,1.14$, and $1.0{ }^{\circ} \mathrm{C}$ per decade for minimum, mean, and maximum TA respectively. These are one of the highest increases of mean TA on the planet, more than 6 times higher than the global average of $+0.17^{\circ} \mathrm{C}$ per decade (NOAA, 2020). The rest of the world is not expected to experience such changes until the end of this century (Hanssen-Bauer et al., 2019). The results of trend analyses for mean monthly TA (min, mean, and max) are presented in Table 2. In almost all months there are statistically significant trends except March. In all analysed cases 
the estimated slope of trend has positive values and indicated the increase in TA. A comparison of the results between variables shows that the largest changes were found for minimum daily TA $\left(1.34^{\circ} \mathrm{C}\right.$ per decade), while the lowest changes were found for the maximum daily TA $\left(1.0^{\circ} \mathrm{C}\right.$ per decade). Taking into account changes between months, the largest changes were estimated for January, February, and December (larger than $2.0^{\circ} \mathrm{C}$ per decade for minimum and mean daily TA). The smallest statistically significant are trends in July and August with slopes of the trend around $0.3^{\circ} \mathrm{C}$ per decade.

Figure $2 \mathrm{~b}$ shows the box plots of monthly averages of minimum, mean, and maximum daily TA from the period 1979-2018. The variability of TA depends on the season, with the highest amplitudes during winter months. Summer TA is rather constant, with monthly means reaching usually slightly below $5.0^{\circ} \mathrm{C}$. Average monthly TA during winter and early spring usually drop below $-10.0^{\circ} \mathrm{C}$. The results are in general accordance with observations made at other Arctic stations and reveal that winter is characterised by the highest variability of TA (Gjelten et al., 2016; Osuch and Wawrzyniak, 2016, 2017a). The amplitude between the extreme high and low in this season may be several times higher than in summer. These fluctuations are determined by the relatively stable anticyclonic subsidence with extreme cold and the turbulent cyclonic disturbances that bring higher temperatures, greater cloudiness, and heavy precipitation. The lowest recorded TA measured at a $2 \mathrm{~m}$ height above solid ground at Hornsund station was $-35.9^{\circ} \mathrm{C}$ on 16 January 1981 , while the absolute maximum was $15.6^{\circ} \mathrm{C}$ on 31 July 2015 . Mean annual air temperature (MAAT) in long-term 1979-2018 is $-3.7^{\circ} \mathrm{C}$. The average coldest month is March with a mean TA of $-10.2^{\circ} \mathrm{C}$, and on average the warmest month is July with a mean TA of $4.6^{\circ} \mathrm{C}$. The coldest month on record with a mean of $-17.9^{\circ} \mathrm{C}$ was January 1981 , and the warmest July 2016 with a mean of $6.3^{\circ} \mathrm{C}$. Additionally, in the dataset we also provided monthly and annual positive (PDD) and negative degree days (NDD), calculated as the sum total of daily mean temperatures above or below the $0^{\circ} \mathrm{C}$ respectively.

\subsection{Air humidity}

The water vapour drives multiple atmospheric processes and has a significant influence on the global climate. It is the main greenhouse gas, affecting the surface by feedback cycle through changing energy balance through radiative fluxes and cloud formation. According to general concepts, the Arctic warming of recent decades is accompanied by the hydrological cycle intensification (Vihma et al., 2016; Osuch et al., 2019). To understand the variability of water vapour concentration and its causes is highly important, especially for climate studies as well as in water balance calculations. At the Hornsund station, the air humidity is currently measured by sensor HMP155, which replaced the previously used HMP45D sensor. The observations cover the period

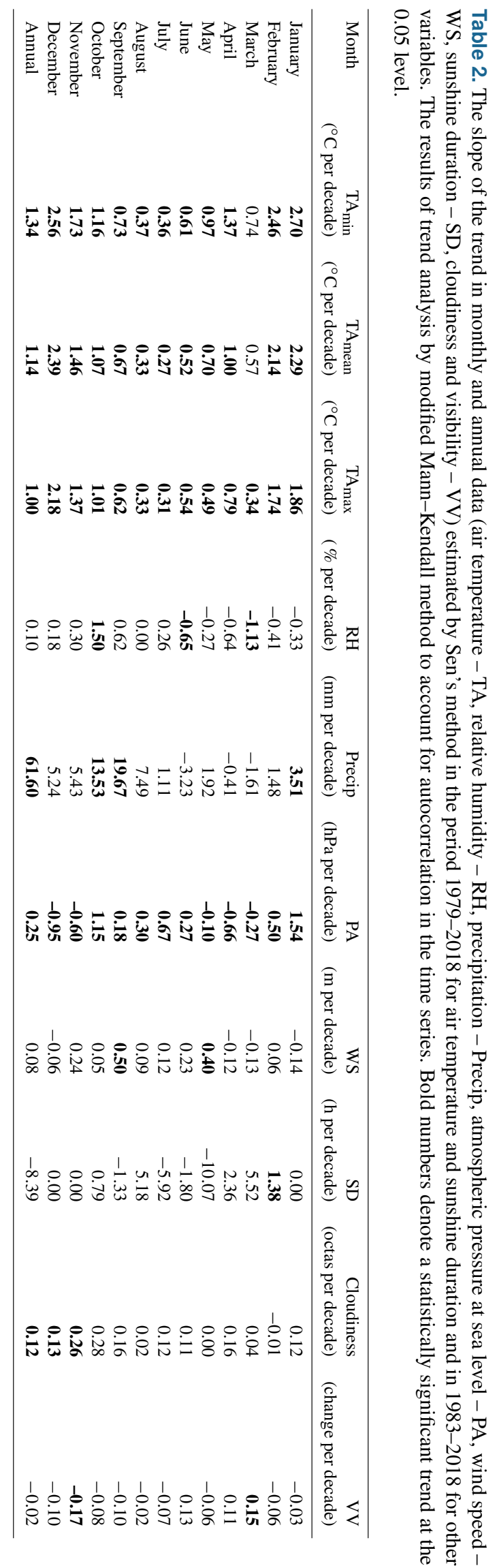

www.earth-syst-sci-data.net/12/805/2020/ 
(a)

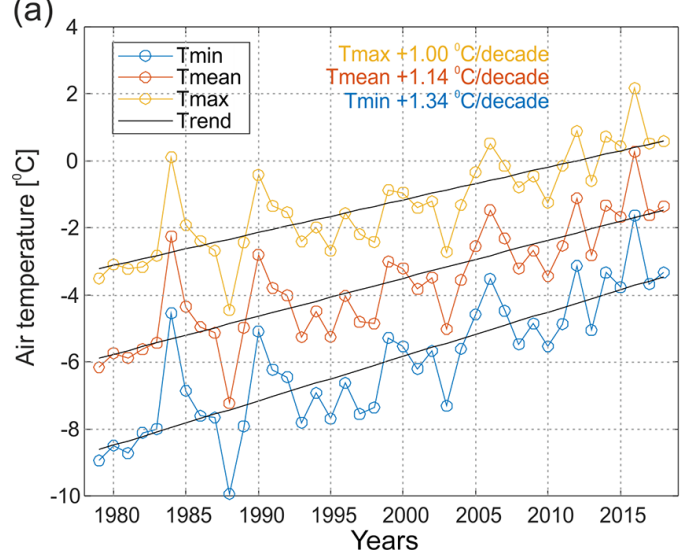

(b) 10

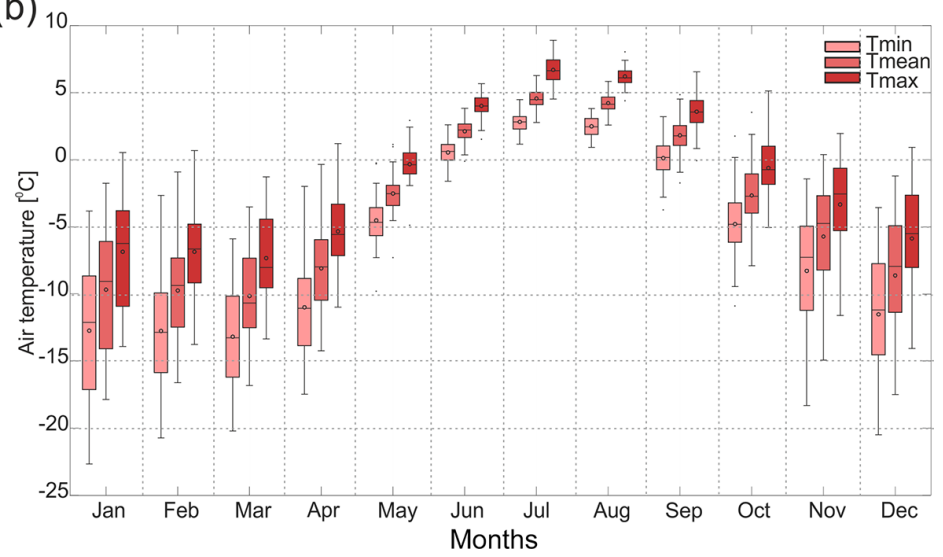

Figure 2. (a) Variability of an annual mean of min, mean, and max air temperatures in 1979-2018. (b) Variability of the monthly mean of min, mean, and max air temperatures in 1979-2018. On each box, the central line indicates the median, the circle represents the mean, and the bottom and top edges of the box indicate the 25th and 75th percentiles, respectively. The whiskers that extend to the most extreme data points are not considered outliers, and the outliers are plotted individually as dots.

1979-2018, but measurements were performed four times a day (00:00, 06:00, 12:00, 18:00 UTC) within the periods 1 July 1978-26 July 1981 and 16 August 1982-31 July 1986, two times a day (06:00 and 18:00 UTC) from 27 July 1981 to 30 June 1982, and eight times a day (00:00, 03:00, 06:00, 09:00, 12:00, 15:00, 18:00, 21:00 UTC) since 1 August 1986. Daily time series of the relative humidity (RH) was calculated as a mean of all available measurements within a particular day. There is a gap in the measurements from 1 July 1982 to 15 August 1982. Therefore the trend analyses were performed for the period 1983-2018.

The variability of the annual mean RH in the period 1983 2019 is presented in Fig. 3a. The average over the period $1983-2018$ is $79.7 \%$. The range of variability is from $75.7 \%$ (2003) to $82.7 \%$ in 1994 . The trend analyses indicated a statistically insignificant trend.

The course of the monthly mean RH in the period 19832018 is presented in Fig. 3b. Higher values of mean RH are observed in warmer months of the year and lower during winter. Such high values are attributed to continual dominance of marine air masses. The annual course of the RH is strongly connected with the air temperature and shows typical variability. It generally increases with warmer air temperatures. However, most of the trends are not statistically significant at the 0.05 level except March, June, and October.

The analyses at daily timescale indicated that drops of $\mathrm{RH}$ below $50 \%$ are recorded rather sporadically, although these can occur throughout the year. Such situations are connected with advection of strongly cooled air masses, foehn effects, or katabatic winds from Hansbreen (Marsz and Styszyńska, 2013). The minimum observed quantity reached $24 \%$ on 15 January 1981. The maximum of the observed RH is equal to $100 \%$. Such conditions occurred 27 times in the period 1979-2018.

\subsection{Precipitation}

In the case of precipitation, the daily sum at the Hornsund station is calculated from four measurements obtained from an unfenced Hellmann rain gauge at 12:00, 18:00, and 00:00, 06:00 of the following day, with the orifice $200 \mathrm{~cm}^{2}$, placed $1 \mathrm{~m}$ above the ground level. The time series of the daily sum of precipitation cover the period 1979-2018 with a gap in July 1982.

The influence of the West Spitsbergen Current creates a relatively moist climate in SW Spitsbergen region, which is clearly reflected in the amount of precipitation. In comparison to the other meteorological stations in Spitsbergen (Osuch and Wawrzyniak, 2017a; Hanssen-Bauer et al., 2019), the annual amount reaching $477 \mathrm{~mm}$ is the highest. The variability of the annual sums of precipitation in the period 1983 2018 is shown in Fig. 4a. The amount of precipitation varies from $230 \mathrm{~mm}$ in 1987 to $805.5 \mathrm{~mm}$ in 2016 . The trend analyses indicated large changes, an increase of $61.6 \mathrm{~mm}$ per decade for the annual sums of precipitation.

The annual course of monthly sums of precipitation from the period 1983-2018 is presented in Fig. 4b. The driest months are April and May with averages of 23 and $24 \mathrm{~mm}$ respectively. The highest precipitation is recorded in September reaching on average $75 \mathrm{~mm}$. Trend analyses presented in Table 2 indicate statistically significant changes in January (3.51 $\mathrm{mm}$ per decade), September $(19.67 \mathrm{~mm} /$ decade), and October (13.53 mm per decade).

\subsection{The atmospheric pressure}

The measurements of the atmospheric pressure (PA) at Hornsund started in July 1978. In the beginning, PA was measured with a mercury barometer every $3 \mathrm{~h}$. Since 2001 measurements have been conducted every $60 \mathrm{~s}$ with a Vaisala 

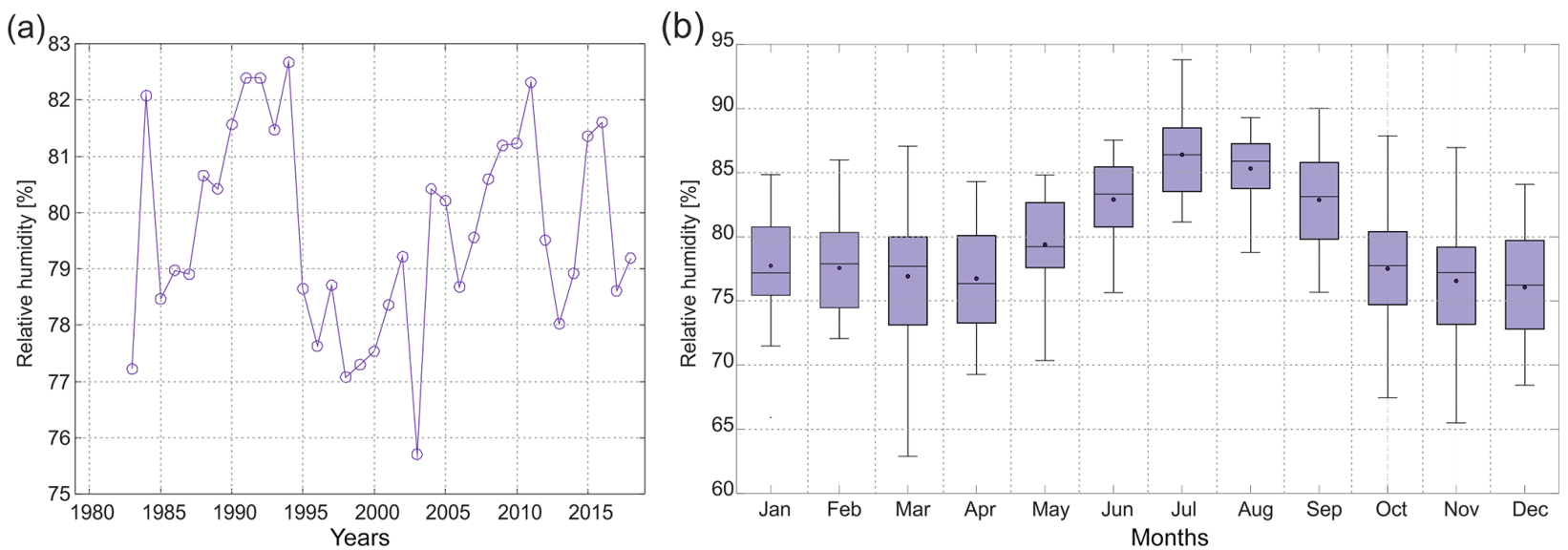

Figure 3. (a) Variability of an annual mean of relative humidity in 1983-2018 at Hornsund. (b) Variability of mean monthly relative humidity in 1983-2018 at Hornsund.
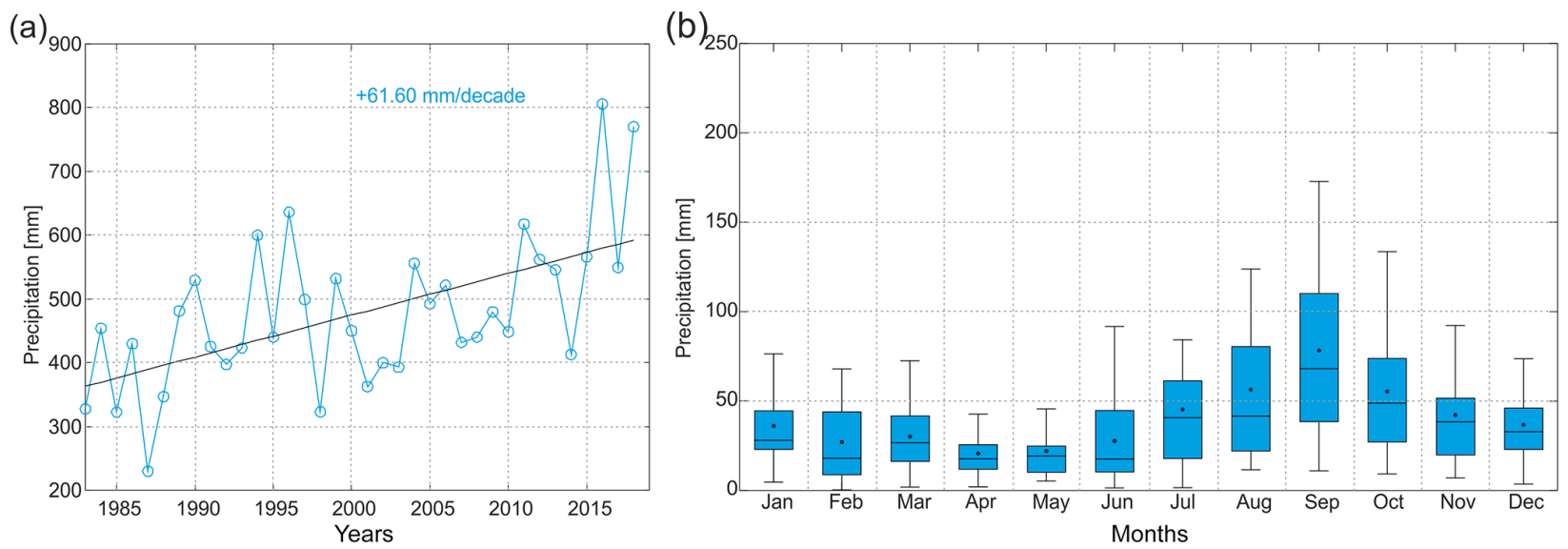

Figure 4. (a) Variability of annual sums of precipitation in 1983-2018 at Hornsund. (b) Variability of mean monthly sums of precipitation in 1983-2018 at Hornsund.

PTB200A sensor, replaced by BARO-1QML_AV in 2018. The lowest recorded PA reduced to sea level at Hornsund station was $982.2 \mathrm{hPa}$ on 30 August 1994, while the absolute maximum was $1028.5 \mathrm{hPa}$ on 7 August 1987. Mean annual PA in long-term $1983-2018$ is $1008.7 \mathrm{hPa}$, and its variability is presented in Fig. 5a. An increasing trend $(0.25 \mathrm{hPa}$ per decade) is visible, but it is statistically insignificant ( $p_{\text {val }}>$ $0.05)$.

Figure $5 \mathrm{~b}$ shows the variability of the mean monthly PA over the period 1983-2018. Well-pronounced seasonality is visible, with a mean monthly pressure higher than $1010 \mathrm{hPa}$ from April to August. The month with the lowest mean PA is December with a mean of $1002.7 \mathrm{hPa}$, and the month with the largest PA is May with a mean of $1015.7 \mathrm{hPa}$. The variability of mean monthly PA within the observation period also is visible with the largest variability in January and February (larger than $30 \mathrm{hPa}$ ) and the smallest in July $(13.7 \mathrm{hPa})$. The trend analyses of mean monthly PA resulted in a statistically insignificant trend for all months.

\subsection{Wind speed and direction}

The wind is a result of atmospheric circulation and is highly correlated with the intensity of cyclonic activity (Przybylak, 2016). The wind regime results from the latitudinal shape of the Hornsund fjord, location near the seashore and local topography. The measurements of wind speed (WS) and wind direction (WD) were performed at Hornsund with different sensors: 1978-2000 with the Fuess 90z wind meter, 20012017 with Vaisala WAA151 for direction and wind speed, since 2018 with Ultrasonic Wind Sensor WMT702. At Hornsund station the height of the anemometer is $10 \mathrm{~m}$ above the ground, around $20 \mathrm{~m}$ above sea level. WS is measured with an accuracy of $0.1 \mathrm{~m} \mathrm{~s}^{-1}$ and WD with $5^{\circ}$. The wind rose for the Hornsund station is presented in Fig. 6. Winds blowing from the east, along the fjord, are prevailing.

The variability of the mean annual WS at Hornsund in the period 1983-2018 is shown in Fig. 7a. The average over the period 1983-2018 is equal to $5.5 \mathrm{~m} \mathrm{~s}^{-1}$. The lowest values of WS were observed in $1985\left(4.8 \mathrm{~m} \mathrm{~s}^{-1}\right)$, while the largest ones 

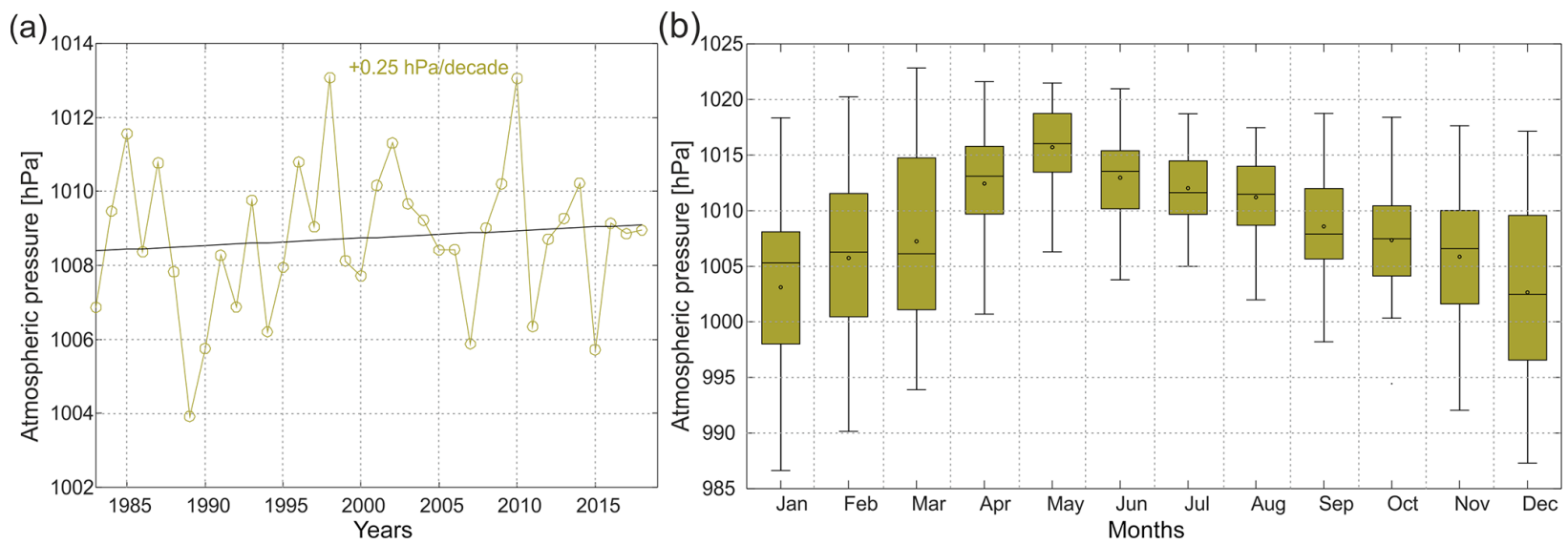

Figure 5. (a) Variability of mean annual air pressure reduced to sea level in 1983-2018 at Hornsund. (b) Variability of mean annual air pressure reduced to sea level in 1983-2018 at Hornsund.

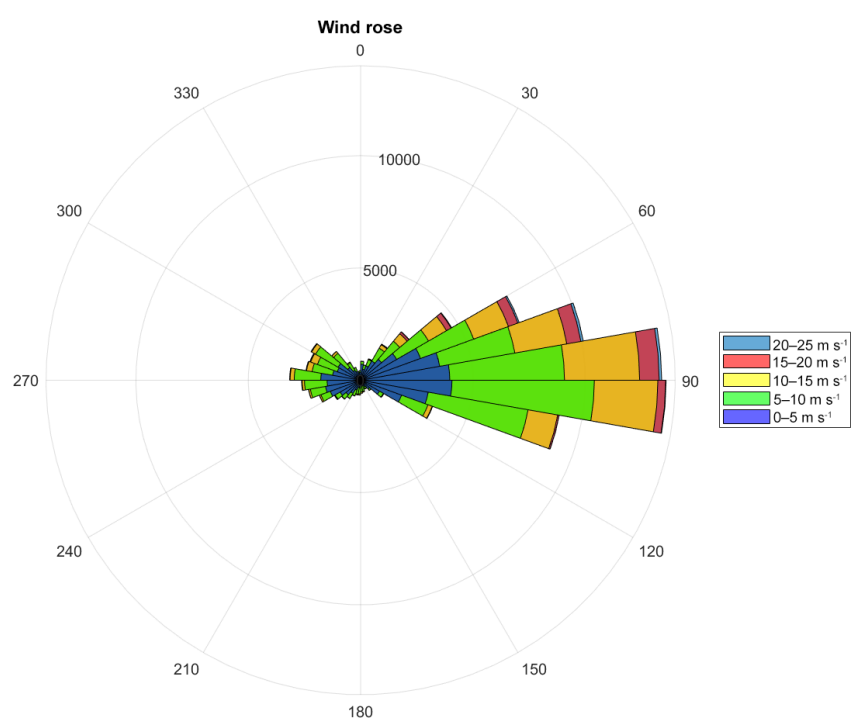

Figure 6. The wind rose for the Hornsund station for the period 1983-2018.

were observed in $1998\left(6.3 \mathrm{~m} \mathrm{~s}^{-1}\right)$. There is a statistically insignificant trend in mean annual WS.

The variability of mean monthly WS in the period 19832018 is presented in Fig. 7b. WS regime is well visible with smaller average values during summer months (minimum $4.0 \mathrm{~m} \mathrm{~s}^{-1}$ in June) and larger average values during winter (maximum $7.1 \mathrm{~m} \mathrm{~s}^{-1}$ in February). Such variability is a result of the extreme cyclone events that often occur during Arctic winters (Rinke et al., 2017).

\subsection{Sunshine duration}

Sunshine duration (SD) is one of the important meteorological variables that provides data on the time period during which direct solar radiation reaches the Earth's surface and partly on the quantity of total solar energy. Daily SD is measured at Hornsund using a Campbell-Stokes sunshine recorder (CS). It uses a direct optical method with the heat energy of the Sun's direct radiation burning the card. Such a traditional sunshine recorder has been in service worldwide since the 19th century; although there are multiple automatic radiometers used simultaneously at the Hornsund station, the longest data are recorded by CS. The time series of sunshine duration cover the period 1983-2018. At the Hornsund station, the polar night lasts $104 \mathrm{~d}$ (31 October-11 February), while the polar day lasts $117 \mathrm{~d}$ (24 April-18 August).

Figure 8a shows the variability of the annual sums of SD at Hornsund in the period 1979-2018. The mean value is $1030.8 \mathrm{~h}$, which is about $28 \%$ of the potential SD calculated for the station (Wojkowski et al., 2015). The large span in the annual SD is visible. The minimum value $(755.4 \mathrm{~h})$ was observed in 1994 and the maximum (1325.6 h) in 1985 . The slightly decreasing trend in SD is visible but statistically insignificant at the 0.05 level.

Monthly total SD is presented in Fig. 8b. Its variability results from the different duration of the day at the location (latitude $77^{\circ} \mathrm{N}$ ) with zero SD during the polar night.

\subsection{Cloudiness}

Arctic clouds have a warming effect on the surface during most of the year because their effect of increasing the downward longwave radiation dominates their effect of reducing the net solar radiation over high-albedo snow and ice surfaces. In summer, however, clouds typically have a cooling effect on surface types with a lower albedo, such as the open sea, melting sea ice, and ground (Intrieri et al., 2002; Shupe and Intrieri, 2004). Observations of cloudiness at the Polish Polar Station in Hornsund are conducted by meteorologists and describe the predominant sky condition based upon octas (eighths) of the sky covered by opaque (not transparent) clouds. There are many factors that may hinder the het- 
(a)

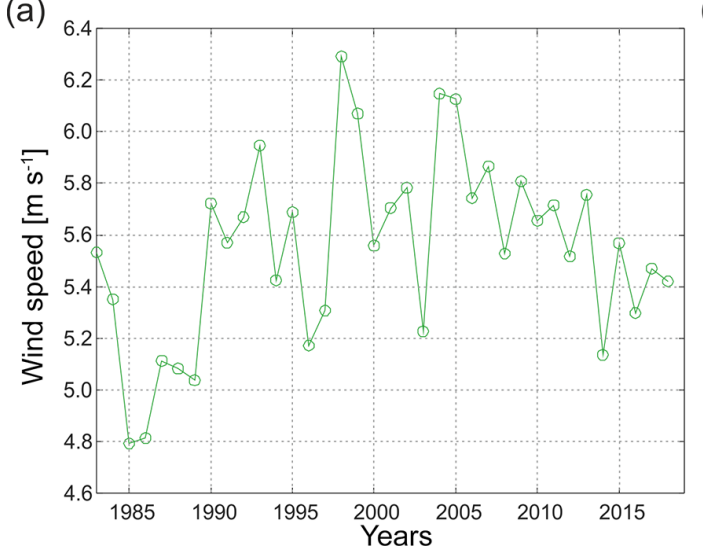

(b)

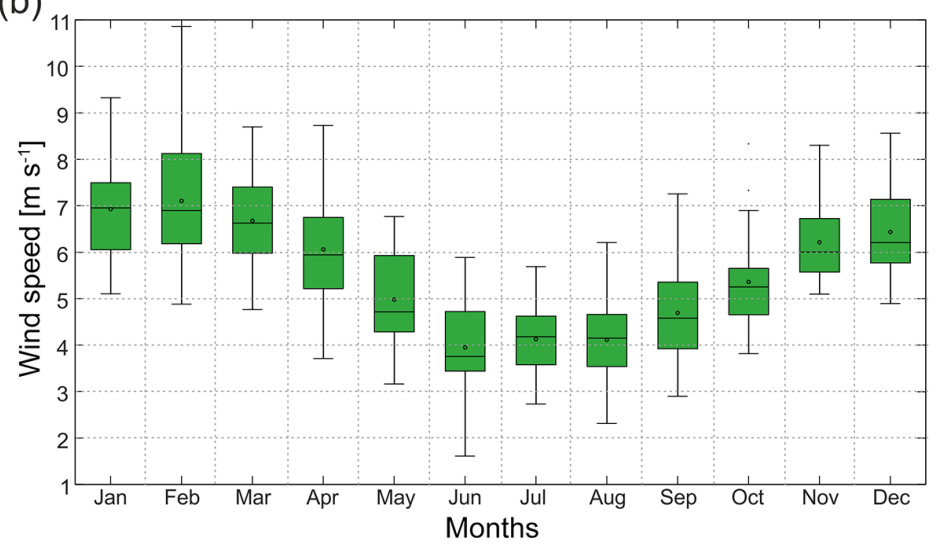

Figure 7. (a) Variability of mean annual wind speed in 1983-2018 at Hornsund. (b) Variability of the mean monthly wind speed at Hornsund in the period 1983-2018.
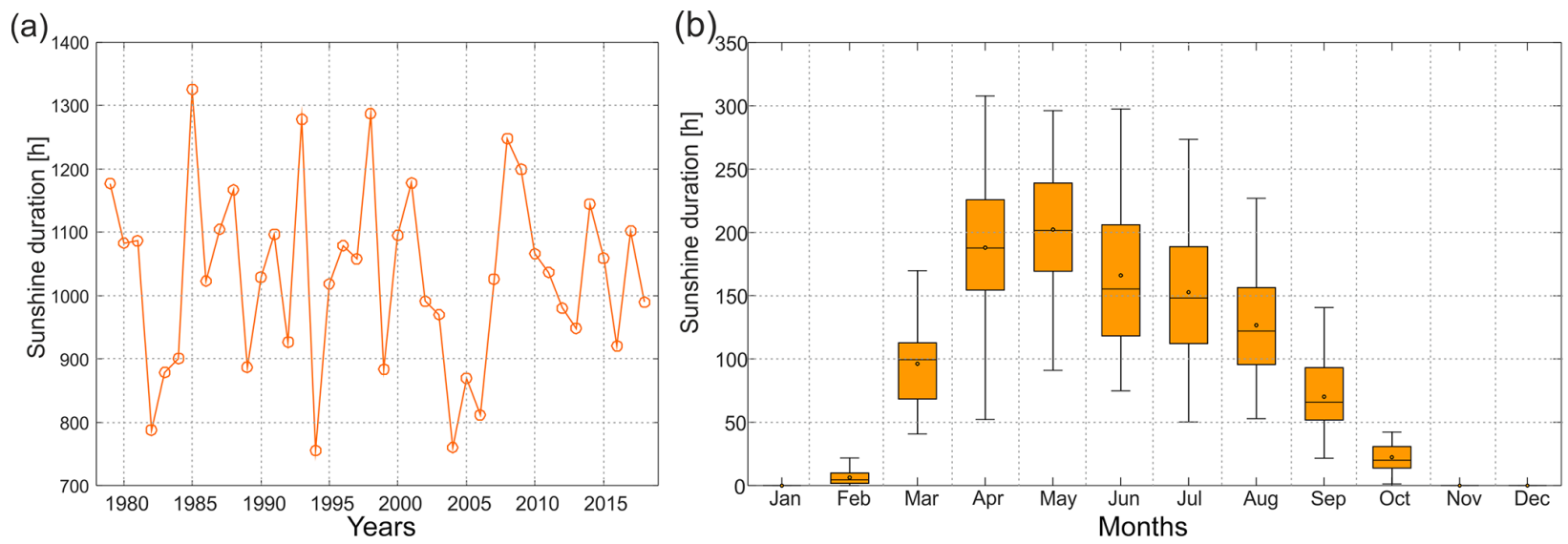

Figure 8. (a) Variability of mean annual sunshine duration in 1979-2018 at Hornsund. (b) Variability of the monthly sums of sunshine duration at Hornsund in the period 1979-2018.

erogeneity and evaluation of cloudiness, due to the annual change in the meteorological observers and the fact that observers might be subjective, although they are provided with clear observable criteria.

Annual averages of cloudiness in the period 1983-2018 are presented in Fig. 9a. The mean over this period equals 5.85 octas. The minimum value of annual mean was observed in 1988 (5.16 octas) and the maximum in 1984 (6.39 octas). An increasing tendency of mean annual cloudiness is visible. The estimated trend (slope 0.13 octas per decade) is statistically significant at the 0.05 level.

The variability of the monthly cloudiness in the period 1983-2018 is presented in Fig. 9b. The annual cycle is characterised by lower mean cloudiness during the cold period from October till April (5.5-6.0 octas), and this period is also characterised by large interannual variability. The period from May till September is on average cloudier (6.0-6.7 octas), and interannual variability is lower.

\subsection{Visibility}

The horizontal visibility is quantified using observations made by meteorologists in the surroundings of the Hornsund station with a marine scale that ranges from 1 to 9 . The visual observations are performed using known distances to the surrounding mountains and other objects. Values 1 and 2 correspond to very bad visibility, $0-50$ and $50-200 \mathrm{~m}$, respectively. Bad visibility $(200 \mathrm{~m}-1 \mathrm{~km})$ is represented by a value of 3 . Weak horizontal visibility represents conditions with 1-2 and 2-4 km that are quantified as 4 and 5 in the applied scale. Moderate horizontal visibility, described as 6 in the scale, represents conditions when an object or light can be clearly discerned from 4 to $10 \mathrm{~km}$. Good horizontal visibility ( 7 in the scale) is $10-20 \mathrm{~km}$, very good (8) $20-50 \mathrm{~km}$, and extremely good (9) is for horizontal visibility larger than $50 \mathrm{~km}$. Noted visibility might be reduced by multiple factors, including all products of the condensation of water vapour such as fog, precipitation, and darkness during cloudy conditions throughout the polar night, as there are no artificial 

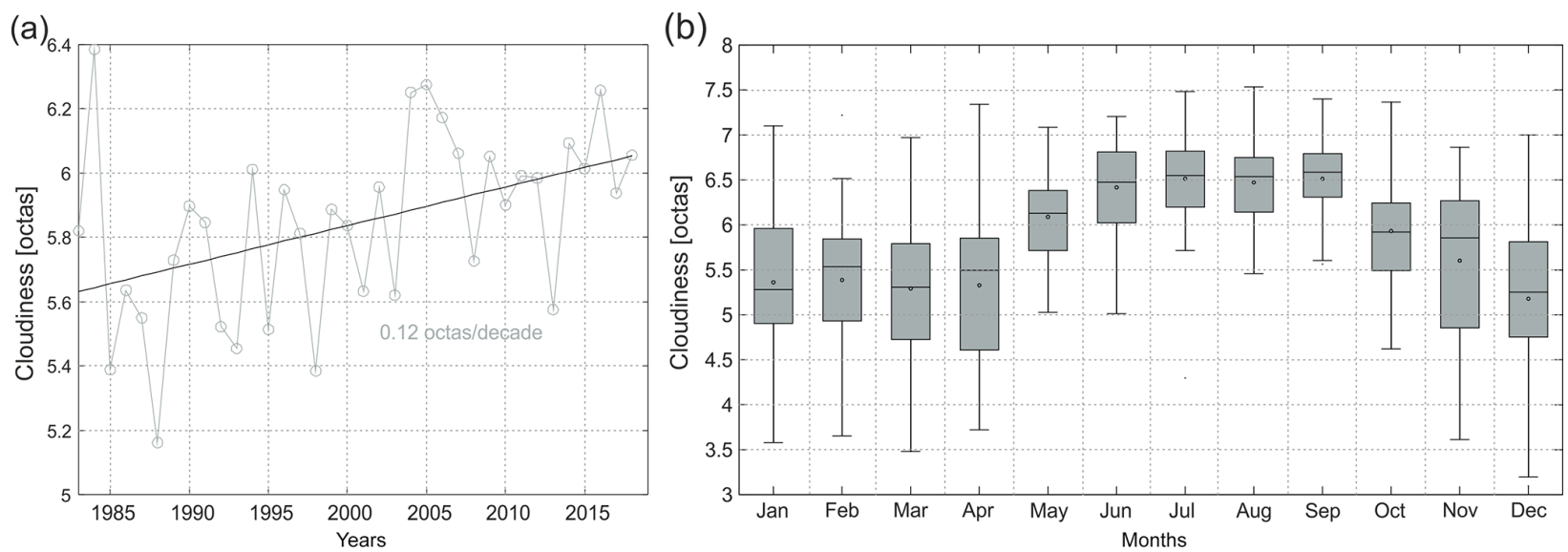

Figure 9. (a) Variability of mean annual cloudiness in 1983-2018 at Hornsund. (b) Variability of the monthly sums of cloudiness at Hornsund in the period 1983-2018.
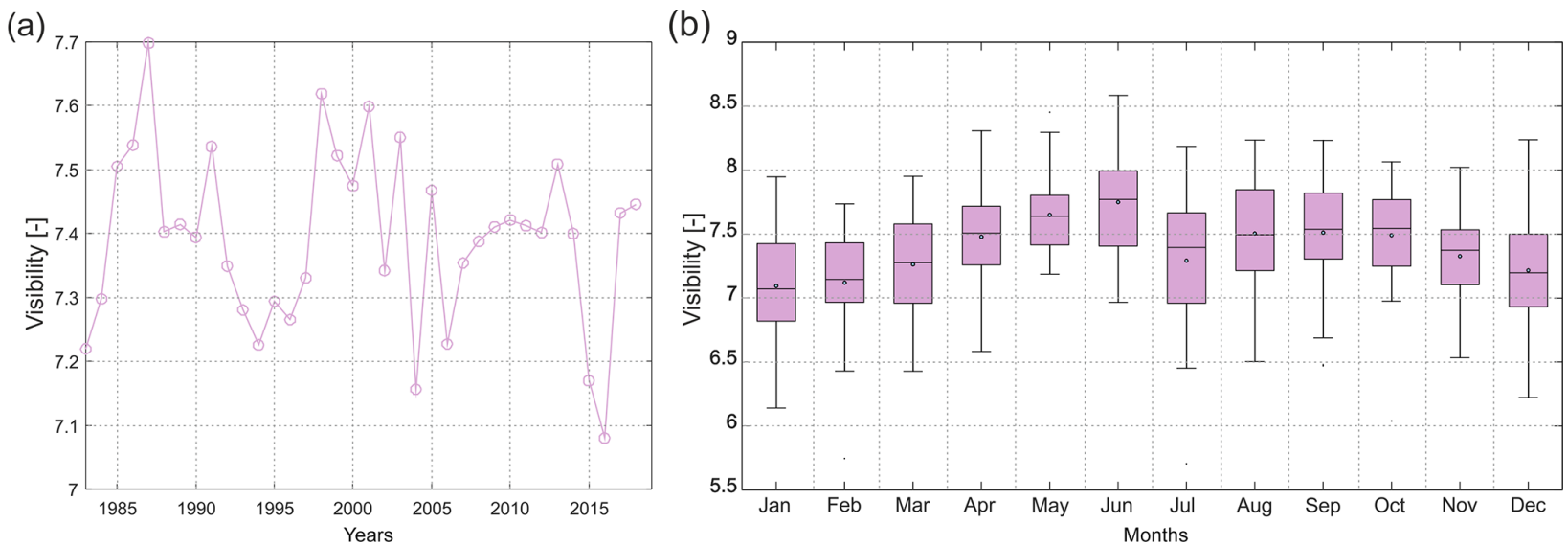

Figure 10. (a) Variability of mean annual visibility in 1983-2018 at Hornsund. (b) Variability of the mean monthly visibility at Hornsund in the period 1983-2018.

lights in the area. There are no anthropogenic factors that would reduce visibility in the vicinity of the Hornsund station as it is located in the middle of the strictly protected South Spitsbergen National Park. Due to that, reduced visibility cannot be an indicator of poor air quality on the local scale.

Figure 10a shows the variability of mean annual visibility in the period 1983-2018. On average in this period, there is good horizontal visibility that amounts to 7.40 ; minimum mean annual visibility was observed in 2016 (7.08), while a maximum was observed in 1987 (7.70). A decreasing tendency is visible (slope of trend -0.02 per decade); however the trend is statistically insignificant at the 0.05 level. Variability of the mean monthly visibility at Hornsund in the period 1983-2018 is presented in Fig. 10b. It is characterised by both low interannual and interseasonal variability and on average reaches values between 7 and 8 .

\section{Quality control of the time series}

All presented datasets have undergone a thorough quality control process. Such a process consisted of multiple steps as the measurements may not be homogenous due to the varying number of observations during the day, changes of sensors, and other factors (Estévez et al., 2011). In the first step, the data were visualised as a time series that allowed verification if all data had been collected and the record structure were correct, complete, and without any gaps. In this way also the presence of outliers and step change in the data was tested. To determine the degree of compatibility and homogeneity of the measurements from different sensors, which changed over the years, the old and new sensors were operated simultaneously for more than 1 year. The results allowed us to combine time series. In the following step, different variables were compared to test the internal consistency between variables. Such analyses include a comparison of minimum, mean, and maximum daily TA that follow the 
rule $\mathrm{TA}_{\max }>\mathrm{TA}_{\text {mean }}>\mathrm{TA}_{\text {min. }}$. In the case of WS and $\mathrm{WD}$, the following conditions were tested: $\mathrm{WS}=0$ and $\mathrm{WD}=0$, $\mathrm{WS} \neq 0$ and $\mathrm{WD} \neq 0$. In the third step temporal consistency of time series was analysed with the help of statistical tests of homogeneity (Pettit and the standard normal homogeneity test). In the last step, the same variables but from different meteorological stations in Svalbard were compared. The air temperature time series were tested against observations in Barentsburg, Bjørnøya, Hopen, Longyearbyen (Svalbard Lufthavn), Ny Ålesund, and Sveagruva. For that purpose, the data were visualised and checked with the standard normal homogeneity test (Alexandersson, 1986; Nordli et al., 1996). The applied algorithm showed good performance in both detecting breakpoints and identifying homogeneous time series. By application of the relative method, with comparison to the other available datasets from Svalbard, the gradual and step changes due to climate change were not found to be a source of inhomogeneity.

\section{Data availability}

The dataset described in this article is available on the PANGAEA repository (https://doi.org/10.1594/PANGAEA.909042, Wawrzyniak and Osuch, 2019).

\section{Summary}

This paper has presented details of a long-term (1979-2018) dataset from the meteorological site at the Polish Polar Station Hornsund located in the SW part of Spitsbergen. The data series includes daily, monthly, and annual air temperature, PDD, NDD, the sum of precipitation, air humidity, atmospheric pressure, wind speed and direction, sunshine duration, cloudiness, and visibility. This rich dataset, now available online, is a valuable source for documenting the state of the climate in SW Spitsbergen, which represents the Atlantic sector of the Arctic. With the positive trend of mean annual temperature of $+1.14^{\circ} \mathrm{C}$ per decade in the last four decades (1979-2018), the climate in Hornsund is warming in this period more than 6 times higher than the global average, which amounts to $+0.17^{\circ} \mathrm{C}$ per decade (NOAA, 2020). All climatological variables presented in this study have many environmental implications, and there are both broad scientific interest and societal need to understand climate variability and its influence on geoecosystems.

Author contributions. TW and MO wrote the paper and carried out the data processing and analysis.

Competing interests. The authors declare that they have no conflict of interest.
Acknowledgements. The authors would like to kindly thank the meteorological staff from the Polish Polar Station Hornsund (listed here: https://hornsund.igf.edu.pl/about-the-station/ expeditions/, last access: 1 April 2020) for collecting the data and maintaining the meteorological monitoring. The authors also thank the two anonymous reviewers for valuable comments and suggestions. Financial support for this work was provided by the Polish National Science Centre through grant no. 2017/27/B/ST10/01269. This work was also partially supported by the Institute of Geophysics, Polish Academy of Sciences within statutory activities no. 3841/E-41/S/2020 of the Ministry of Science and Higher Education of Poland.

Financial support. This research has been supported by the Polish National Science Centre (grant no. 2017/27/B/ST10/01269) and the Ministry of Science and Higher Education of Poland (grant no. 3841/E-41/S/2020).

Review statement. This paper was edited by Jens Klump and reviewed by two anonymous referees.

\section{References}

Alexandersson, H.: A homogeneity test applied to precipitation data, J. Climatol., 6, 661-675, https://doi.org/10.1002/joc.3370060607, 1986.

Araźny, A., Przybylak, R., Wyszyński, P., Wawrzyniak, T., Nawrot, A., and Budzik, T.: Spatial variations in air temperature and humidity over Hornsund fjord (Spitsbergen) from 1 July 2014 to 30 June 2015, Geogr. Ann. A, 100, 27-43, https://doi.org/10.1080/04353676.2017.1368832, 2018.

Błaszczyk, M., Jania, J. A., and Kolondra, L.: Fluctuations of tidewater glaciers in Hornsund Fjord (Southern Svalbard) since the beginning of the 20th century, Pol. Polar Res., 34, 327-352, https://doi.org/10.2478/popore-2013-0024, 2013.

Dahlke, S., Hughes, N. E., Wagner, P. M., Gerland, S., Wawrzyniak, T., Ivanov, B., and Maturilli, M.: The observed recent surface air temperature development across Svalbard and concurring footprints in local sea ice cover, Int. J. Climatol., https://doi.org/10.1002/joc.6517, online first, 2020.

Estévez, J., Gavilán, P., and Giráldez, J. V.: Guidelines on validation procedures for meteorological data from automatic weather stations, J. Hydrol., 402, 144-154, https://doi.org/10.1016/j.jhydrol.2011.02.031, 2011.

Gjelten, H. M., Nordli, Øyvind, Isaksen, K., Førland, E.J., Sviashchennikov, P. N., Wyszynski, P., Prokhorova, U. V., Przybylak, R., Ivanov, B. V., and Urazgildeeva, A. V.: Air temperature variations and gradients along the coast and fjords of western Spitsbergen, Polar Res., 35, 29878, https://doi.org/10.3402/polar.v35.29878, 2016.

Hamed, K. H. and Rao, R.: A modified Mann-Kendall trend test for autocorrelated data, J. Hydrol., 204, 182-196, 1998.

Hanssen-Bauer, I., Førland, E. J., Hisdal, H., Mayer, S., Sandø, A. B., Sorteberg, A., Adakudlu, M., Andresen, J., Beldring, S., Benestad, R., Bilt, W., Bogen, J., Borstad, C., Breili, K., Breivik, Ø., Børsheim, K. Y., Christiansen, H. H., Dobler, A., Engeset, 
R., Frauenfelder, R., Gerland, S., Gjelten, H. M., Gundersen, J., Isaksen, K., Jaedicke, C., Kierulf, H., Kohler, J., Li, H., Lutz, J., Melvold, K., Mezghani, A., Nilsen, F., Nilsen, I. B., Nilsen, J. E. Ø., Pavlova, O., Ravndal, O., Risebrobakken, B., Saloranta, T., Sandven, S., Schuler, T. V., Simpson, M. J. R., Skogen, M., Smedsrud, L. H., Sund, M., Vikhamar-Schuler, D., Westermann, S., and Wong, W. K.: Climate in Svalbard 2100 - a knowledge base for climate adaptation. Norwegian Centre for Climate Services, Report no. 1/2019, ISSN 2387-3027, 205 pp., 2019.

Intrieri, J. M., Fairall, C. W., Shupe, M. D., Persson, P. O. G., Andreas, E. L., Guest, P., and Moritz, R. M.: An annual cycle of Arctic surface cloud forcing at SHEBA. J. Geophys. Res., 107, 8039, https://doi.org/10.1029/2000JC000439, 2002.

IPCC: The Ocean and Cryosphere in a Changing Climate, available at: https://www.ipcc.ch/srocc/home/ (last access: 1 April 2020), 2019.

Kendall, M. G.: Rank Correlation Methods, Charles Griffin, London, 1975.

Lindner, L., Marks, L., Roszczynko, W., and Semil, J.: Age of raised marine beaches of northern Hornsund Region, South Spitsbergen, Pol. Polar Res., 12, 161-182, 1991.

Mann, H.: Nonparametric tests against trend, Econometrica, 13), 245-259, https://doi.org/10.2307/1907187, 1945.

Marsz, A. A. and Styszyńska, A.: Climate and Climate change at Hornsund, Svalbard, Gdynia Maritime University, Gdynia, Poland, 2013.

NOAA: National Centers for Environmental information, Climate at a Glance, Global Time Series, available at: https://www.ncdc. noaa.gov/cag/, last access: 27 February 2020.

Nordli, Ø., Przybylak, R., Ogilvie, A. E. J., and Isaksen, K.: Longterm temperature trends and variability on Spitsbergen: the extended Svalbard Airport temperature series, 1898-2012, Polar Res., 33, 21349, https://doi.org/10.3402/polar.v33.21349, 2014.

Nordli, P. Ø., Hanssen-Bauer, I., and Førland, E. J.: Homogeneity Analyses of Temperature and Precipitation Series from Svalbard and Jan Mayen, Norwegian Meteorol. Inst. Report 16/96 KLIMA, 41 pp., 1996.

Osuch, M. and Wawrzyniak, T.: Climate projections in the Hornsund area, Southern Spitsbergen, Pol. Polar Res., 37, 379-402, https://doi.org/10.1515/popore-2016-0020, 2016.

Osuch, M. and Wawrzyniak, T.: Inter- and intra-annual changes of air temperature and precipitation in western Spitsbergen, Int. J. Climatol., 37, 3082-3097, https://doi.org/10.1002/joc.4901, 2017a.

Osuch, M. and Wawrzyniak, T.: Variations and changes in snow depth at meteorological stations Barentsburg and Hornsund (Spitsbergen), Ann. Glaciol., 58, 11-20, https://doi.org/10.1017/aog.2017.20, 2017b.

Osuch, M., Wawrzyniak, T., and Nawrot, A.: Diagnosis of the hydrology of a small Arctic permafrost catchment using HBV conceptual rainfall-runoff model, Hydrol. Res., 50, 459-478, https://doi.org/10.2166/nh.2019.031, 2019.
Przybylak, R.: The climate of the Arctic, Atmospheric and Oceanographic Sciences Library 52, Heidelberg, Springer, 2nd Edn., 287 pp., https://doi.org/10.1007/978-3-319-21696-6, 2016.

Rinke, A., Maturilli, M., Graham, R. M., Matthes, H., Handorf, D., Cohen, L., Hudson, S. R., and Moore, J. C.: Extreme cyclone events in the Arctic: Wintertime variability and trends, Environ. Res. Lett., 12, 094006, https://doi.org/10.1088/17489326/aa7def, 2017.

Sen, P. K.: Estimates of the regression coefficient based on Kendall's tau, J. Am. Stat. Assoc., 63, 1379-1389, https://doi.org/10.2307/2285891, 1968.

Shupe, M. D. and Intrieri, J. M.: Cloud radiative forcing of the Arctic surface: The influence of cloud properties, surface albedo, and solar zenith angle, J. Climate, 17, 616-628, https://doi.org/10.1175/15200442(2004)017<0616:CRFOTA>2.0.CO;2, 2004.

van Pelt, W., Pohjola, V., Pettersson, R., Marchenko, S., Kohler, J., Luks, B., Hagen, J. O., Schuler, T. V., Dunse, T., Noël, B., and Reijmer, C.: A long-term dataset of climatic mass balance, snow conditions, and runoff in Svalbard (1957-2018), The Cryosphere, 13, 2259-2280, https://doi.org/10.5194/tc-13-22592019, 2019.

Vihma, T., Screen, J., Tjernström, M., Newton, B., Zhang, X., Popova, V., Deser, C., Holland, M., and Prowse, T.: The atmospheric role in the Arctic water cycle: A review on processes, past and future changes, and their impacts, J. Geophys. Res.-Biogeo., 121, 586-620, https://doi.org/10.1002/2015JG003132, 2016.

Walczowski, W., Beszczynska-Möller, A., Wieczorek, P., Merchel, M., and Grynczel, A.: Oceanographic observations in the Nordic Sea and Fram Strait in 2016 under the IO PAN longterm monitoring program AREX, Oceanologia, 59, 187-194, https://doi.org/10.1016/j.oceano.2016.12.003, 2017.

Wawrzyniak, T. and Osuch, M.: A consistent High Arctic climatological dataset (1979-2018) of the Polish Polar Station Hornsund (SW Spitsbergen, Svalbard), PANGAEA, https://doi.pangaea.de/10.1594/PANGAEA.909042, 2019.

Wawrzyniak, T., Osuch, M., Napiórkowski, J. J., and Westerman, S.: Modelling of the thermal regime of permafrost during 1990 2014 in Hornsund, Svalbard, Pol. Polar Res., 37, 219-242, https://doi.org/10.1515/popore-2016-0013, 2016.

Wawrzyniak, T., Osuch, M., Nawrot, A., and Napiórkowski, J. J.: Run-off modelling in an Arctic unglaciated catchment (Fuglebekken, Spitsbergen), Ann. Glaciol., 58, 36-46, https://doi.org/10.1017/aog.2017.8, 2017.

Wojkowski, J., Caputa, Z., and Leszkiewicz, J.: The impact of relief on the diversity of possible sunshine duration at Hornsund region (SW Spitsbergen), Problemy Klimatologii Polarnej, 25, 179-190, 2015. 